\title{
SCIENTIFIC LITERACY: HOW IS IT EVOLVED TO PRE- SERVICE PHYSICS TEACHER?
}

\author{
Muhammad Minan Chusni*1, Rizki Zakwandi², Aan Hasanah' ${ }^{3}$, Adam Malik ${ }^{4}$, Adeng \\ Muchtar Ghazali ${ }^{5}$, Mujib Ubaidillah ${ }^{6}$ \\ 1, 2,4 Department of Physics Education, UIN Sunan Gunung Djati. Jl. A.H Nasution No 105, Bandung, Indonesia \\ ${ }^{3}$ UIN Sunan Gunung Djati. Jl. A.H. Nasution No 105, Bandung, Indonesia \\ ${ }^{5}$ UIN Sunan Gunung Djati. Jl. A.H Nasution No. 105, Bandung, Indonesia \\ ${ }^{6}$ IAIN Syekh Nurjati Cirebon, Indonesia \\ *Corresponding Address; minan.chusni@uinsgd.ac.id
}

Received: July $30^{\text {th }}, 2018$. Accepted: October $24^{\text {th }}, 2018$. Published: October $28^{\text {th }}, 2018$

\begin{abstract}
Scientific literacy is the ability to use scientific knowledge, identify problems, and draw conclusions based on evidence, in order to understand and make decisions about nature and changes that occur in nature as a result of human activity. This study aims to determine the development of physics teacher candidates' scientific literacy. This is important to prepare the physics teachers in the future. The method used was ex-post facto. The subjects of this research were all students of physics education Department of UIN Sunan Gunung Djati Bandung from the first to the last semester. The data collection used was essayed tests which contained the context of science, the content of science, the process of science, and the attitude of science. Data analysis was done qualitatively and quantitatively. Based on the results of this study, it indicates that the scientific literacy ability possessed by physics teacher candidate students experiencing a continuous development in terms of the context of science, science content, the process of science, and attitude to science. The result of this research may be applied by the Physics Department to make a decision or rule on how to improve the physics student' literacy level.
\end{abstract}

(C) 2018 Physics Education, UIN Raden Intan, Lampung, Indonesia.

Keyword: physics teachers, professional teacher, scientific literacy

\section{INTRODUCTION}

Scientific literacy has long received attention from the academic field. Scientific literacy is a very important ability for everyone to solve problems. People who have the literacy ability is able to read and understand graphs, tables, diagrams, and able to apply mathematical skills in their life (Vieira \& TenreiroVieira, 2016). While someone who has scientific literacy is a person, who uses scientific knowledge and skills to make decisions to understand life and to participate in social activities (Luke, 2018; Restivo, 2017).

The scientific literacy is directly correlated with building a new generation that has strong scientific thinking and attitude (Linder, Airey, Mayaba, \& Webb, 2014). It can effectively communicate science and research results to the general public (Arohman, Safudin, \& Priyandoko, 2016). The United States National Science Education Standard states that the nation has set a goal for all students to be able to reach the level of scientific literacy (C. Y. Chang, Chang, \& Yang, 2009; Wright, Franks, Kuo, McTigue, \& Serrano, 2016).

Scientific literacy learning has become widespread as one of the most important in science education. The scientific literacy assumptions consist of the ability to think metacognitive, read and write scientific texts, and to apply elements of scientific argumentation (Orr \& Kukner, 2015). According to Butler and Winne in Wallace that metacognitive knowledge needs to be developed by students in order for their learning to be more effective (Bovill, Cook-Sather, Felten, Millard, \& MooreCherry, 2016; Wallace, 2004). Reading and writing skills are also very important 
in literacy, according to Holliday in Wallace, by reading we could know the skill of outlining the ideas and information obtained from the text being read, whereas by getting used to writing will train the ability to express ideas with what is in their hearts in their own language (Roos, 2014). As for applying scientific argumentation, according to Pitrinch in Wallace can be applied after accustomed to writing and reading scientific texts (JohnsonGlenberg, Megowan-Romanowicz, Birchfield, \& Savio-Ramos, 2016; Wallace, 2004).

Learning in science education literacy according to Doyle describes three versions: (a) student-centered, where learning is designed to be in the personal meaning and experience of the child, (b) the subject matter, the lesson is designed to align with professional work and discipline, (c) learning center in world activities real where it will be an experience for every individual. To achieve the goal of science literacy, teachers and science educators should concentrate on instructional design for student learning or on student performance (August \& Shanahan, 2017; S. N. Chang \& Chiu, 2005).

The Ministry of National Education has developed a curriculum policy study in science subjects with facts about PISA results on the average literacy conditions of Indonesian students. So far, the acquisition of Indonesian students' literacy index is still very low. This is in line with Indonesia's rating according to the Program for International Students Assessment (PISA), which occupies the 62nd position of 69 countries evaluated (Iswadi, 2016).

This study was conducted based on the Curriculum Centre of the National Education Research and Development Agency on the Future Science Curriculum. Based on such study resulted in science learning related to science literacy. Some of the things recommended in the academic script are: (1) Science learning should be able to foster students' selfesteem, (2) science learning must be accompanied by the development of skills and skill skills and scientific skills, so that science learning not only teaches concepts, (3) Science learning should make students able to develop their reasoning ability and can plan to conduct scientific investigation, (4) Science learning should be able to revitalize science process skill for students, teachers and prospective teachers as the main mission of Teaching and Learning Process of science (Islami, Nahadi, \& Permanasari, 2016). Simply, the research aim is to show the level of student literacy of physics content and to give consideration to be applied by the department.

\section{METHOD}

The approach used in this research was descriptive quantitative approach with special study characteristic. The method used in this research was an ex-post facto method. This research explains the influence of literacy ability for physics teacher candidate. Researchers took 41 students of Physics Education Department of UIN Sunan Gunung Djati Bandung as the randomly selected subject. The data in this research was obtained from the instrument of scientific literacy with four aspects of literacy namely process, concept, context, and attitude. The subject matter in this research was gear and spring matter that has been learned by the student in senior high school or basic physics in university. The instrument was validated by the specialist, and the reliability was calculated using Spearman-Brown methods. An assessment was done by using four-levels rubric according to the true level of the answer (Zakwandi, Rochman, Nasrudin, Yuningsih, \& Putra, 2018). The data was then analyzed by a quantitative approach to get the profile of student ability and to predict the literacy level of the student in the last years. Before 
that, the data has been checked through statistical approach such as reliability or normality of the data. Reliability has the same function as the standard deviation is to show the distribution of the result.

\section{RESULTS AND DISCUSSION}

The data in this study was collected from the instrument of scientific literacy. Before the data was used to make a conclusion of the result, the data was checked through the validity and reliability test and give the result as the coefficient of reliability with the value 0,92 with the very high interpretation (Crowder, 2017) and the validity of each number of question is:

Table 1. The validity of instrument literacy of each question

\begin{tabular}{cccc}
\hline No & $\begin{array}{c}\text { Number of } \\
\text { Question }\end{array}$ & Index & $\begin{array}{c}\text { Qualificati } \\
\text { on }\end{array}$ \\
\hline 1 & 1 (Process) & 0.55 & Middle \\
2 & 2 (Concept) & 0.75 & High \\
3 & 3 (Context) & 0.70 & High \\
4 & 4 (Attitude) & 0.78 & High \\
5 & 5 (Process) & 0.88 & Very High \\
6 & 6 (Concept) & 0.79 & High \\
7 & 7 (Context) & 0.82 & Very High \\
8 & 8 (Attitude) & 0.85 & Very High \\
\hline
\end{tabular}

Based on table 1 we get the information that the instrument of literacy used in this research was reliable and possessed a high-level degree of validity. So we can to use the data from this instrument to make a conclusion and generalization of the students' levels of literacy in Physics Education Department (Chatfield, 2018).

The result of this study indicates that the scientific literacy possessed by the students of physics teacher candidate experiencing a continuous development during the learning process. Based on the data obtained, the student ability increases significantly.
Table 2. Student average score in mechanic's phenomenon

\begin{tabular}{ccc}
\hline No & Year & Average \\
\hline 1 & 2017 & 1.35 \\
2 & 2016 & 2.07 \\
3 & 2017 & 2.65 \\
\hline
\end{tabular}

Table 2 shows the level of students' scientific literacy ability at the beginning (first years) to the end (third year). Based on the table, we have the data of the improvement of the students' scientific literacy with the coefficient of 1,40 each year. The data indicate that the students' level in the first years was low, the students in the second years was in the moderate scientific literacy ability and the student in the third years was in the high-level category. In addition, the data obtained shows that the overall average of students in the aspect of scientific literacy was still in the moderate category with the achievement of 2.02 on a scale of 0 to 4 (Towns \& Ashby, 2014). This provides an illustration that the implementation of learning that had been done to help students to develop their scientific literacy level was still not enough since society requires them to be highly literate. Based on the assumption, the increase of student literacy could be used to predict that the Physics Education Program students would have a high level of literacy, thus it can be assumed that the graduates are already at a high level. However, this still needs to be improved further because of the score is still in the unsafe level (Drew \& Thomas, 2018).

Table 3. Students' scientific literacy Levels on Gear and spring matter

\begin{tabular}{llcc}
\hline \multirow{2}{*}{ No } & \multirow{2}{*}{ Year } & \multicolumn{2}{c}{ Average } \\
\cline { 3 - 4 } & & Gear & Spring \\
\hline 1 & 2017 & 1.77 & 0.92 \\
2 & 2016 & 2.43 & 1.70 \\
3 & 2017 & 2.73 & 2.56 \\
\hline
\end{tabular}

Based on Table 3, the difference in student literacy level was observed from the material tested. In this study, the 
material used as research was the material related to gear, chain, and spring. Based on the data obtained then it appears that the subjects of the research were more literate on the material related to wheel and chain compared with the spring material. This is because of the subjects were in touch directly with the wheels and chains more than the springs (Proyowidodo \& Luik, 2014). In the real-life application, the wheel and chain are represented by Ferriswheel whereas spring material is represented by a sledgehammer. Based on the data obtained, the level of students' literacy on the material related to wheel and chain was in the intermediate level with the score of 2.31 while the material related to springs was in the low level with the score of 1.73 from a $0-4$ scale. If it is reviewed further on the basis of each scientific literacy aspect (process, concept, context, and attitude), it shows more specific results. Table 4 shows the level of students' literacy on each aspect of literacy in each material tested. In every aspect of students' scientific literacy also shows higher levels in the wheel and chain material compared to spring material. In the aspect of data process, the students were more familiar with the process of moving or working principle of FerrisWheel than a sledgehammer. This is due to the experience of the average student who had been on a Ferris-Wheel, and only a few of the students have ever used a sledgehammer (Rainey, Maher, Coupland, Franchi, \& Moje, 2018). Based on these results it can be shown that one way to increase the level of literacy is by presenting the real form of a physics concept. The results showed that students have the highest level of literacy on the process in both materials while for the lowest score are in the attitude aspect. This indicates that the student still can't give a proper view in addressing the application of the physics concept. This is true also related to the acquisition of literacy index on the concept aspect in each material where the students only get the score of 2.18 on wheel and chain material and 1.76 for the spring material (Soobard \& Rannikmae, 2011).

Table 4. Student literacy levels each aspect on each matter study

\begin{tabular}{llcc}
\hline \multirow{2}{*}{ No } & \multirow{2}{*}{ Aspect } & \multicolumn{2}{c}{ Index } \\
\cline { 3 - 4 } & & Gear & Spring \\
\hline 1 & Process & 2.69 & 2,09 \\
2 & Concept & 2.18 & 1.76 \\
3 & Context & 2.48 & 1.54 \\
4 & Attitude & 1.89 & 1.64 \\
\hline
\end{tabular}

This is slightly different in the context aspect in which the students have a fairly good score on wheel and spring material. This may indicate that the students were able to predict how the impact of the application will be. The overall cumulative result of the student literacy index is shown in Table 5.

Table 5. Student literation index of each aspect literacy

\begin{tabular}{cccc}
\hline No & Aspect & Index & $\begin{array}{c}\text { Qualificati } \\
\text { on }\end{array}$ \\
\hline 1 & Process & 2.39 & Moderate \\
2 & Concept & 1.97 & Low \\
3 & Context & 2,01 & Moderate \\
4 & Attitude & 1.71 & Low \\
& Average & 2.02 & Moderate \\
\hline
\end{tabular}

Table 5 shows that the level of student' literacy is at a moderate level. The obtained literacy index based on the literacy aspect shows that the new students get the highest score (Dong, Chai, Sang, Koh, \& Tsai, 2015). This thorough discussion indicates that the average students' literacy index obtained is still at the moderate level and even very close to the low literacy level in the range of 1.01 2.00. This does not fully reflect how the implementation of the learning is done (Asyhari \& Asyhari, 2017). Furthermore, the development of students' literacy index in every aspect of literacy is shown in Figure 1. 


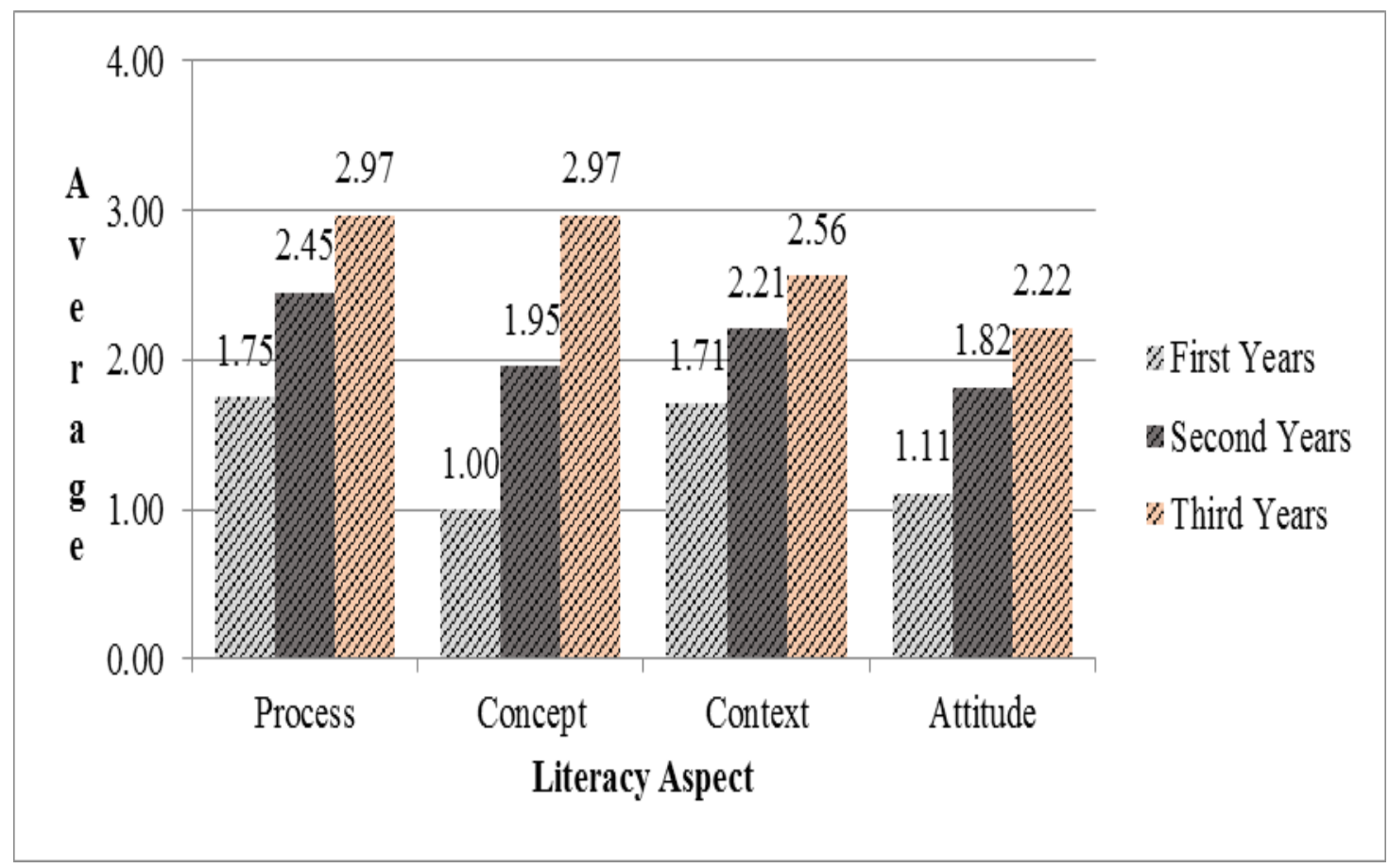

Figure 1. Student Literacy Levels each aspect of science literation.

Figure 1 shows that the students' scientific literacy index of each aspect has increased from the first year to the third year. The most significant increase occurred in the concept aspect where the first-year students gained a score of 1.00 while in the third-year students gained a score of 2.97. which has the same value with the index on the aspect of the process. The smallest increase occurred in the context aspect ( 0.85 from initial ability). However, this can be masked by a relatively high initial willingness of 1.71 (Supeno, Subiki, \& Rohma, 2018). The next smallest increase was in the attitude aspect that increased by 1.11 from the initial ability into 1.11. Overall, it can be seen that the lesson learned can significantly improve the student literacy index. Especially in the concept and process aspects which shows the increase of 1.97 and 1.22 from the initial capability. Based on the data, it can be described how the learning process was undertaken to improve student conceptual understanding (Connor et al., 2017).

\section{CONCLUSION}

Student literacy skills related to the application of physics concepts on wheel and chain and spring material have improved along with the learning experience. Both on the whole and on the literacy aspect, students' scientific literacy skills increased significantly. A high level of improvement occurred in the conceptual mastery aspects reaching threefold compared to the students' ability in the first year. While the lowest increase occurred in the aspects of content that is only $85 \%$ compared to the first year. However, this is covered with a high initial ability. The overall level of student literacy is at a moderate level (years 1 - 3) with an index of 2.02 on a scale of $0-4$. This can indicate that the level of students' literacy still needs to be improved.

\section{REFERENCES}

Arohman, M., Safudin, \& Priyandoko, D. (2016). Kemampuan Literasi Sains Siswa pada Pembelajaran Ekosistem. In Prosiding Seminar Biologi (pp. 90-92).

Asyhari, A., \& Asyhari, A. (2017). Literasi 
Sains Berbasis Nilai-Nilai Islam dan Budaya Indonesia. Jurnal Ilmiah Pendidikan Fisika Al-Biruni, 6(1), 137.

https://doi.org/10.24042/jpifalbiruni. v6i1.1584

August, D., \& Shanahan, T. (2017). Developing literacy in secondlanguage learners: Report of the National Literacy Panel on Language-Minority Children and Youth. Rouledge.

Bovill, C., Cook-Sather, A., Felten, P., Millard, L., \& Moore-Cherry, N. (2016). Addressing potential challenges in co-creating learning and teaching: overcoming resistance, navigating institutional norms and ensuring inclusivity in student-staff partnerships. Higher Education, $71(2)$, 195-208. https://doi.org/10.1007/s10734-0159896-4

Chang, C. Y., Chang, Y. H., \& Yang, F. Y. (2009). Exploring Secondary Science Teachers' Perceptions on the Goals of Earth Science Education in Taiwan. International Journal of Science Education, 31(17), 2316.

Chang, S. N., \& Chiu, M. H. (2005). The Development of Authentic Assessments to Investigate ninth Graders' Scientific Literacy: In The Case of Scientific Cognition Concerning The Concepts of Chemistry and Physics. International Journal of Science and Mathematics Education, 3.

Chatfield, C. (2018). Introduction to Multivariate Analysis. Routledge. https://doi.org/10.1201/97802037499 99

Connor, C. M., Dombek, J., Crowe, E. C., Spencer, M., Tighe, E. L., Coffinger, S., ... Petscher, Y. (2017). Acquiring science and social studies knowledge in kindergarten through fourth grade: Conceptualization, design, implementation, and efficacy testing of content-area literacy instruction (CALI). Journal of Educational Psychology, 109(3), 301-320. https://doi.org/10.1037/edu0000128

Crowder, M. (2017). Statistical Analyse of Reliability Data. Routledge.

Dong, Y., Chai, C. S., Sang, G.-Y., Koh, J. H. L., \& Tsai, C.-C. (2015). Exploring the Profiles and Interplays of Pre-service and In-service Teachers' Technological Pedagogical Content Knowledge (TPACK) in China. Journal of Educational Technology \& Society. International Forum of Educational Technology \& Society. https://doi.org/10.2307/jeductechsoci .18.1.158

Drew, S. V., \& Thomas, J. (2018). Secondary science teachers' implementation of CCSS and NGSS literacy practices: a survey study. Reading and Writing, 31(2), 267291. https://doi.org/10.1007/s11145017-9784-7

Islami, R. A. Z. El, Nahadi, N., \& Permanasari, A. (2016). Membangun Literasi Sains Siswa Pada Konsep Asam Basa Melalui Pembelajaran Inkuiri Terbimbing. Jurnal Penelitian Dan Pembelajaran IPA, 2(2), 110 120.

https://doi.org/10.30870/JPPI.V2I2.6 62

Iswadi, H. (2016). Sekelumat dari Hasil PISA 2015 yang Baru Dirilis.

Johnson-Glenberg, M. C., MegowanRomanowicz, C., Birchfield, D. A., \& Savio-Ramos, C. (2016). Effects of Embodied Learning and Digital Platform on the Retention of Physics Content: Centripetal Force. Frontiers in Psychology, 7, 1819. https://doi.org/10.3389/fpsyg.2016.0 1819

Linder, A., Airey, J., Mayaba, N., \& Webb, P. (2014). Fostering Disciplinary Literacy? South African Physics Lecturers' Educational Responses to 
their Students' Lack of Representational Competence. African Journal of Research in Mathematics, Science and Technology Education, 18(3), 242252.

https://doi.org/10.1080/10288457.20 14.953294

Luke, A. (2018). The social construction of literacy in the primary school. In Critical Literacy, Schooling and Social Justice (1st ed., pp. 28-74). New York: Routledge.

Orr, A. M., \& Kukner, J. M. (2015). Fostering a creativity mindset in content area pre-service teachers through their use of literacy strategies. Thinking Skills and Creativity, 16, 69-79. https://doi.org/10.1016/J.TSC.2015.0 2.003

Proyowidodo, G., \& Luik, J. (2014). Communicating disaster mitigation literacy to coastal communities in Pacitan, Indonesia. American International Journal of Research in Humanities, Arts and Social Sciences, 5(2), 245-248.

Rainey, E. C., Maher, B. L., Coupland, D., Franchi, R., \& Moje, E. B. (2018). But What Does It Look Like? Illustrations of Disciplinary Literacy Teaching in Two Content Areas. Journal of Adolescent \& Adult Literacy, 61(4), 371-379. https://doi.org/10.1002/jaal.669

Restivo, S. (2017). The Social Construction of Mathematics. In Sociology, Science, and the End of Philosophy (pp. 253-281). London: Palgrave Macmillan UK. https://doi.org/10.1057/978-1-34995160-4_7

Roos, J. M. (2014). Measuring science or religion? A measurement analysis of the National Science Foundation sponsored science literacy scale 2006-2010. Public Understanding of Science, 23(7), 797-813. https://doi.org/10.1177/09636625124 64318

Soobard, R., \& Rannikmae, M. (2011). Assesing student's levels of scientific literacy using interdisiplinary scenarios. Science Education International, 22(2), 133-144.

Supeno, S., Subiki, S., \& Rohma, L. W. (2018). Students' Ability In Solving Physics Problems on Newtons' Law of Motion. Jurnal Ilmiah Pendidikan Fisika Al-Biruni, 7(1), 59-70. https://doi.org/10.24042/jipfalbiruni. v7i1.2247

Towns, E., \& Ashby, S. (2014). The influence of practice educators on occupational therapy students, understanding of the practical applications of theoretical knowledge: A phenomenological study into student experiences of practice education. Australian Occupational Therapy Journal, 61(April), 344-352. https://doi.org/10.1111/14401630.12134

Vieira, R. M., \& Tenreiro-Vieira, C. (2016). Fostering Scientific Literacy and Critical Thinking in Elementary Science Education. International Journal of Science and Mathematics Education, 14(4), 659-680. https://doi.org/10.1007/s10763-0149605-2

Wallace, C. S. (2004). Framing New Research in Science Literacy and Language Use: Authenticity, Multiple Discourses, and the "Third Space. In Framing New Research in Science Literacy and Language Use: Authenticity, Multiple Discourses, and the "Third Space (p. 902).

Wright, K. L., Franks, A. D., Kuo, L.-J., McTigue, E. M., \& Serrano, J. (2016). Both Theory and Practice: Science Literacy Instruction and Theories of Reading. International Journal of Science and Mathematics Education, 14(7), 1275-1292. 
https://doi.org/10.1007/s10763-0159661-2

Zakwandi, R., Rochman, C., Nasrudin, D., Yuningsih, E. K., \& Putra, S. (2018). Profil Literasi Fisika Siswa Madrasah Terhadap Mitigasi Bencana Erosi Batang Sinamar. Jurnal Pendidikan Islam Belajea, 3(1), 47-58. https://doi.org/http://dx.doi.org/10.29 240/bjpi.v3i1.279 